\title{
МІЖНАРОДНІ-ПРАВОВІ СТАНДАРТИ У СФЕРІ ЗАПОБІГАННЯ ТА ПРОТИДІЇ НАСИЛЬСТВУ ЩОДО ДІТЕЙ
}

\author{
ШУТКА Володимир Ярославович - здобувач другого (магістерського) рівня \\ вищої освіти Національного університету біоресурсів і природокористування \\ України
}

DOI 10.32782/EP.2021.4.19

В научной статье определено, что на сегодня насилие является одной из остръгх соииальньх проблем как Украинь, так и всего мирового сообщества. Его жертвами одновременно могут становиться как женщинъ, так и мужчинъ, однако, по международной статистике, большая часть насильственньхх действий направляется именно на женщин и детей. Определено, ито каждъй ребенок имеет право на физическую и личную неприкосновенность и зашиту от всех форм насилия. Проанализированъ статистические даннъе относительно проявлений насилия в отношении детей в Украине и мире. Исследована генеза международно-правовых документов, которве призвань предотвратить и противодействовать любым проявлениям насилия в отношении детей. Определено к международноправовым документам, призваннвгх регулировать данную сберу является Женевская декларация прав ребенка, Декларащия прав ребенка, Конвениия ООН о правах ребенка, Всемирная декларация об обеспечении въживания, защить и развития детей, Факультативный протокол к Конвениии ООН о правах ребенка, относительно торговли детьми, детской проституции и детской порнографии, Протокол о предупреждении и пресечении торговли людьми, особенно женшинами и детьми, и наказании за нее, дополняющий Конвеницю Организации Объединеннъгх Наџий против трансначиональной организованной преступности, Конвениция МОТ № 182 о запрещении и немедленных мерах по искоренению наихудших форм детского труда.

Кроме втого, в процессе исследования было проанализировано национальное законодательство, сбормированное в результате обязательств Украинъ на международной арене. Рассмотрень приниип обеспечения наилучших интересов ребенка в Декларации прав ребенка. Проанализирована практика Европейского суда по правам человека относительно дел, связаннъхх с насилием в отношении детей. Сбормированъ предложения для уменьшения и искоренения насилия, направленного на детей. Внедрение указаннъх положительных мер по предупреждению и ликвидации всех форм насилия в отношении детей и эбббективно реагировать на факть его совершения, исключая безнаказанность злоумыишленников.

Ключевые слова: международно-правовъе стандартьл, насилие в отношении детей, предотвращение и противодействие насилию, международно-правовъе актъи.

Постановка проблеми

Насильство щодо дітей $є$ всесвітньою проблемою, яка щоденно завдає шкоди найціннішим благам дитини - честі, гідності, здоров'ю та життю. 3 насильством дитина може зустрітися всюди: в приміщенні чи на вулиці, в закладі освіти або на відпочинку. Aле найбільш прикро та несправедливо, що дитина може зазнати насильства з боку 


\section{Кримінальне право, кримінальний процес та криміналістика}

своєї ж сім’ї, від рідних та найдорожчих для неї людей. Таке насильство завдає не лише фізичного болю, моральних страждань, але й підриває почуття безпеки, захищеності особи, тримає іï у стані постійного нервового напруження, що може призвести до розладів психіки, депресій, нервових зривів чи розвитку психічного захворювання[1, с. 104].

Світовою громадськістю насильство визнано однією 3 найбільш розповсюджених у світі форм порушення прав людини. У свою чергу, це небезпечне явище спричиняє неможливість створення умов для самореалізації людини, розвитку паритетної демократії, реалізації принципів рівних прав і можливостей кожного громадянина. Як і для більшості країн світу, вищезазначена проблема досить гостро постає й перед Україною. Загальновідомо, що саме в сім'ї формуються основні принципи буття людини, іiі духовні, моральні, світоглядні якості, а від психологічного здоров'я родини багато в чому залежить моральний стан суспільства. Розповсюдження проявів насильства в сім'ї не лише руйнують гармонію і злагоду всередині родини, а у свою чергу, є рушійною силою для розвитку злочинності в суспільстві загалом.

\section{Стан дослідження}

Питання насильства щодо дітей 3 огляду на значне поширення цього явища розглядається як масштабна проблема як на національному, так і на міжнародному рівнях. У розрізі євроінтеграції та відповідно впровадженні міжнародних норм у національне законодавство вважаємо питання дослідження міжнародно-правових стандартів у цій сфері напрочуд актуальним. Серед науковців, які прямо чи опосередковано досліджували цю тематику є наступні : К. Кучерук, О. Зінсу, К. Левченко, Т. Журавель, Е. Яхязаде, О. Руднєва, Г. Христова, А. Ноур, А. Джужа, М. Джиба, Т. Аисенко, С. Кузьменко, Т. Хуторянська та ін.

Метою статті $є$ дослідження міжнародно-правових стандартів у сфері запобігання та протидії насильства щодо дітей та їх вплив на національне законодавство.

\section{Виклад основних положень}

Одним із індикаторів соціальної зрілості суспільства визначають ставлення до дітей, оскільки саме діти - майбутнє кожної держави. У суспільстві, що зорієнтоване на високі загальнолюдські цінності існування, не повинно бути місця будь-яким проявам насильства щодо дітей.

Кожна дитина має право на фізичну та особисту недоторканість та захист від усіх форм насильства. Як зазначається в Загальній декларації прав людини, «діти як людські істоти мають повне право користуватися всіма правами, що їх гарантують різноманітні міжнародні угоди 3 прав людини, які походять із Загальної декларації прав людини» [2]. Діти також мають право на захист, яке закріплено в міжнародно - правових інструментах, пов'язаних 3 міжнародним кримінальним, гуманітарним та трудовим правом.

Незважаючи на це, за статистичними даними Державного інституту сімейної та молодіжної політики в Україні, найчастіше, а саме у $85 \%$, жертвами насильства стають жінки, діти та особи похилого віку тобто ті, хто, напевне, не може за себе постояти і кого можна безкарно скривдити. Проте така ж невтішна статистика спостерігається й у світовому співтоваристві. Так, дані за 2019 рік свідчать про те, що у Німеччині $81 \%$ жертв домашнього насильства - жінки та діти.

Як зазначає К. Кучерук, у світовому масштабі жертвами від домашнього насильства в абсолютній більшості є жінки та діти, які страждають від насильства важче порівняно із чоловіками. Діти, що живуть у домівках 3 насильством, 3 раннього віку виявляють психологічні проблеми, такі як неконтрольована агресія, хронічні проблеми зі здоров'ям, наркоманія, тяжкі психічні порушення, депресія, інвалідність [3, с.101].

Насильство несе дуже серйозні негативні соціальні наслідки. Воно породжує терор, безладдя, відчуття відсутності допомоги, невпевненості, безнадійності або безсилля, відчуття провини, відчуття придушення волі, примари, відсутність самоповаги, настирливі спогади, напади страхів, депресію, фобії, смуток, роздуми про само- 
губство, самозвинувачення, втрату довіри, сумніви щодо віри в щось, наркотичну/ алкогольну залежність, жагу помсти. Мала дитина не може знати, коли відбудеться наступний спалах насильства, де та наскільки сильним він буде. У результаті, вразливість та відсутність контролю над ситуацією призводять до проявів впертості у поведінці, відмови розмовляти та агресивних вчинків.

За даними Е. Назимко, основоположна ж соціальна небезпека цього явища полягає, як відомо, у тому, що саме досвід перебування як жертви злочину накладає на дитину глибоку, жахливу та подекуди, на жаль, невиліковну протягом усього ії подальшого життя соціальну, психологічну та іноді й суто фізичну травму. Дитина, ставши одного разу жертвою того чи іншого злочину, зазнає певної, подекуди й достатньо суттєвої та незворотної десоціалізації, психологічної (психічної), морально-ціннісної фрустрації та, безумовно, таким чином, і власної криміналізації [4, с.158].

Статистичні дані спонукають до розроблення дієвої системи запобігання, протидії, профілактики домашньому насильству, що передбачає вивчення зарубіжного досвіду в зазначеній сфері суспільних відносин і впровадження інтегрованого підходу до вдосконалення національних концепцій, зважаючи на актуальний державно-політичний курс, історичні умови, тип правової системи та соціокультурну казуальність феномену правової реальності [5, с.32].

Саме для вирішення вищезазначених проблем у 1948 році на міжнародній арені було прийнято Загальну декларацію прав людини, яка, у свою чергу, отримала статус першого авторитетного (однак не обов'язкового за законом) твердження про права людини, на основі якого було ухвалено понад 60 міжнародних угод, що стосувалися боротьби з рабством, провадження правосуддя, статусу біженців та меншин, а також прав людини та дитини. Усі вони грунтуються на концепціях недискримінації, рівності та визнання гідності кожної особистості, як це визначається в Загальній декларації. Кожен такий документ також встановлює, що правами, перерахованими у ньому, наділені абсолютно всі люди, у тому числі діти, на засадах рівності.

Діти, за певним винятком, мають ті ж права, що і дорослі. Однак, деякі права мають особливе значення для них - вони відображають потреби дітей у спеціальному захисті та увазі, виявляють їхню вразливість та різницю між дитячим і дорослим життям. Для того, щоб підкреслити це, інтереси дитини у всіх видах діяльності ставляться вище інтересів дорослих та держави [6].

Таким чином, можна дійти до висновку, що діти в рівній мірі володіють правами і є суб'єктами процедур, встановлених Міжнародним біллем 3 прав людини [7], який складається 3 Міжнародного пакту про економічні, соціальні та культурні права та Міжнародного пакту про громадянські і політичні права. Діти також володіють правами та засобами захисту, встановленими спеціальними угодами, зокрема тими, що спрямовані на ліквідацію расової дискримінації, дискримінації проти жінок, попередження тортур, забезпечення прав робітників-мігрантів та членів їхніх родин. Ці інструменти, які мають силу законів у державах, які їх прийняли, включають положення, що стосуються ліквідації насильства щодо дітей. Деякі міжнародні документи, зокрема вказані вище Пакти, також містять положення, що передбачають особливий захист для дітей.

Міжнародні документи у сфері забезпечення реалізації прав дитини гарантують захист усіх прав дітей, базуючись на основоположному принципі найкращих інтересів дитини. До таких документів належать: Женевська декларація прав дитини, 1924 р.; Декларація прав дитини, 1959 р. [8]; Конвенція ООН про права дитини, 1989 р.; Всесвітня декларація про забезпечення виживання, захисту і розвитку дітей, 1990 р.; Факультативний протокол до Конвенції ООН про права дитини, щодо торгівлі дітьми, дитячої проституції і дитячої порнографії, 2000 р.; Протокол про попередження і припинення торгівлі людьми, особливо жінками і дітьми, і покарання за неї, що доповнює Конвенцію Організації Об'єднаних Націй проти транснаціональної організованої злочинності, ратифікований 


\section{Кримінальне право, кримінальний процес та криміналістика}

Україною у 2004 р.; Конвенція МОП № 182 про заборону та негайні заходи щодо ліквідації найгірших форм дитячої праці, ратифікована Україною у 2000 р.; Конвенція Ради Свропи про захист прав людини і основоположних свобод, 1950 р. ; Конвенція Ради Європи про захист дітей від експлуатації і знущань сексуального характеру, СЕД №201, 2007 р. та інші.

Незважаючи на те, що права дітей захищені цілою низкою загальних міжнародних угод з прав людини та іншими міжнародними документами, на перших етапах існування Організації Об'єднаних Націй міжнародне співтовариство визнало за необхідне створити окремий механізм захисту людських прав дитини [9, с.140]. У 1959 року Генеральна Асамблея ООН прийняла Декларацію прав дитини, яка встановлювала 10 головних принципів, що не мають сили закону, спрямованих на забезпечення захисту дітей.

Вищезазначена Декларація встановлює громадянські права (на життя і розвиток, на отримання громадянства, свобода від фізичного та психічного насильства та ін.), соціальні (на охорону здоров'я, на освіту та ін.), культурні (наприклад, право на дозвілля). Старшим дітям Конвенція надає i політичні права (наприклад, право на об’єднання). Натомість у Конвенції майже відсутня увага питанням економічних прав дитини, адже пріоритетом визнано освіту дитина повинна вчитись, а не працювати.

Ратифікувавши Конвенцію $\mathrm{OOH}$ про права дитини, Україна взяла на себе зобов'язання керуватися дотриманням принципу «найкращих інтересів дитини» щодо реалізації державної політики у цій сфері. Як закріплено в ст. 3 Конвенції, «в усіх діях щодо дітей, незалежно від того, здійснюються вони державними чи приватними установами, що опікуються питаннями соціального забезпечення, судами, адміністративними чи законодавчими органами, першочергова увага приділяється якнайкращому забезпеченню інтересів дитини».

На підставі положень Конституції України [10] і Конвенції ООН про права дитини 26 квітня 2001 р. в Україні був прийнятий
Закон «Про охорону дитинства», який визначає охорону дитинства стратегічним загальнонаціональним пріоритетом і з метою забезпечення реалізації прав дитини на життя, охорону здоров'я, освіту, соціальний захист та всебічний розвиток встановлює основні засади державної політики у цій сфері.

Принцип забезпечення найкращих інтересів дитини у Декларації прав дитини визначається як забезпечення дитині, через закони та за допомогою інших засобів, спеціального захисту та надання можливостей і сприятливих умов, що дозволяли 6 дитині розвиватися фізично, розумово, морально, духовно та соціально здоровим в умовах свободи та гідности.

Відповідно до ЗУ «Про охорону дитинства», держава взяла на себе зобов'язання вжити всіх необхідних законодавчих, адміністративних і просвітницьких заходів щодо захисту дітей від насильства у всіх його проявах, образ, зловживань, недбалого піклування або його відсутності [11].

Вихідною ідеєю законодавчого забезпечення прав дітей в Україні $є$ принцип усі «діти рівні у своїх правах незалежно від походження», що закріплено статтею 52 Конституції України. Україна також уперше в Конституції зазначила, що будь-яке насильство над дитиною та її експлуатація переслідуються законом, держава забезпечує гарантії державного утримання та виховання дітей-сиріт і дітей, позбавлених батьківського піклування (ст. 52).

Варто зазначити, що міжнародно - правові стандарти поширення та захисту прав Аюдини і стандартів стосовно протидії насильству щодо дітей, зміцнюються завдяки договорам, які приймаються на регіональному рівні, наприклад, Радою Свропи, Свропейським Союзом, Організацією американських держав, Африканським союзом. Створюють відповідні механізми та їх відстеження та правозастосування. Особливо вагомим регіональним документом $є$ Африканська хартія прав дитини та Африканський протокол з прав жінок, які були прийняті 2004 року.

Регіональні механізми прав людини, які наглядають і контролюють реалізацію таких 
правових інструментів, спрямовували свої зусилля на подолання різних форм насильства щодо дітей. Наприклад, Европейський суд з прав людини виявив порушення Европейської конвенції з прав людини у деяких рішеннях національних судів щодо випадків тілесного покарання в пенітенціарній системі, у закладах освіти та в родинах [12].

Інші рішення Европейського суду стосувалися сексуального насильства, неспроможності систем захисту дітей та ювенальної юстиції. Европейський комітет з соціальних прав, який здійснюе моніторинг відповідності Європейської соціальної хартії та Оновленої соціальної хартії, вимагав, щоб до цих документів була включена законодавча заборона будь-яких форм насильства щодо дітей [13].

У 2002 році Міжамериканський суд 3 прав людини видав Консультативні висновки щодо правового статусу і прав дитини: у них вказано, що держави, які прийняли Американську конвенцію 3 прав людини, повинні вживати всіх заходів для забезпечення захисту дітей від неналежного ставлення, безвідносно їхніх стосунків з державною владою, окремими особами чи неурядовими структурами.

Міжнародні та регіональні договори i угоди 3 прав людини доповнюються засобами та правовими інструментами, які хоч і не мають сили закону і не є обов'язковими до виконання, водночас встановлюють стандарти чи пропонують принципи, що стосуються ліквідації насильства щодо дітей.

Результати всесвітніх конференцій ООН та їхній розгляд на спеціальних сесіях Генеральної Асамблеї також звертають увагу на проблеми насильства щодо дітей. Учасники Спеціальної сесії Генеральної Асамблеї ООН в інтересах дітей 2002 року присвятили насильству щодо дітей значну частину свого підсумкового документа - «Світ, сприятливий для Дітей». Цілі розвитку тисячоліття, прийняті на Самміті Тисячоліття ООН 2000 року, а також Підсумковий документ Саміту ООН 2005 року також містять положення, спрямовані на ліквідацію насильства щодо дітей [14, с.138].

Документи, які не мають сили законів, але водночас є потужними і переконливими інструментами подолання насильства щодо дітей, були також прийняті керівними органами спеціальних агенцій та інших структур системи ООН. Зокрема, це стосується резолюцій керівних органів ВООЗ та ЮНІСЕФ.

Приєднавшись до міжнародних та регіональних договорів, держави приймають на себе юридичні/законні зобов'язання поважати, захищати та виконувати права, які вони визнають. Від держав вимагається утримуватися від втручання у користування правами, захищати людей від насильства 3 боку недержавних суб'єктів та вживати заходів для забезпечення виконання прав людини.

У країнах Східної Європи національні програми щодо запобігання злочинності у сім'ї є менш комплексними і масштабними, ніж у інших країнах Заходу. Проте слід відмітити позитивні зміни у законодавчому регулюванні цієї сфери, які певною мірою сприяють якщо не запобіганню сімейному насильству, то принаймні кращій допомозі жертвам сімейного насильства і покаранню осіб, які вчинили насильство [15, с.122]. Мова йде про скорочення термінів розслідування сімейних злочинів; більш суворі покарання за вчинення злочинів над близькою особою і ще більш суворі покарання за вчинення злочинів над особами, які знаходяться під охороною; право виселення особи, яка вчинила сімейне насильство, із спільного помешкання.

Відтак, що стосується насильства щодо дітей, урядам слід вжити невідкладних та позитивних заходів для попередження та ліквідації всіх форм насильства щодо дітей та ефективно реагувати на факти його вчинення, унеможливлюючи безкарність зловмисників. Держави повинні гарантувати, щоб представники державних органів, наприклад, офіцери поліції чи вчителі у державних школах, не здійснювали насильства щодо дітей. Цього можна досягти через застосування законодавчих або інших заходів для попередження таких дій, наприклад, шляхом навчання поліцейських та інших державних чиновників провадити розслідування без застосування насильства. Державам також необхідно прийняти відповідне законодавство або вжити інших заходів для 


\section{Кримінальне право, кримінальний процес та криміналістика}

захисту дітей та для запобігання або утримання батьків, опікунів та інших неурядових сторін від порушення прав дитини через застосування насильства.

\section{Висновок}

Таким чином, міжнародне право створює потужні, комплексні юридичні засади, які вимагають багатоаспектних дій у відповідь. Такі дії відрізнятимуться залежно від форми насильства та середовища, де воно відбувається. Зокрема, такі дії можуть включати заходи системи громадського здоров'я, спрямовані на попередження; дії кримінального права, компенсації, просвіту, медичні чи законодавчі підходи. Сучасні стандарти міжнародного права, що стосуються насильства щодо дітей, є комплексними та деталізованими. Проблема полягає в тому, щоб забезпечити виконання всіма державами своїх зобов' язань. Системна та поширена природа насильства щодо дітей в усіх іiі формах та середовищах повинна бути визнана. Потім необхідно вжити належних та ефективних законодавчих, політичних та програмних заходів, реалізувати їх на практиці, відстежувати та вдосконалювати їх у такий спосіб, щоб дієво і своєчасно реагувати на цю масштабну глобальну проблему.

\section{Мiтература}

1. Кузьменко С.С. Міжнародний досвід запобігання насильницьким злочинам проти статевої свободи та статевої недоторканості дитини. Правові новели. 2020. №11. T.2. C.101-108. URL: http://legalnovels.in.ua/ journal/11-2_2020/17.pdf (дата звернення $05.10 .2021)$.

2. Загальна декларація прав людини від 10 грудня 1948 p. URL: http://zakon5. rada.gov.ua/laws/show/995_015 (дата звернення: 10.09.2018).

3. Кучерук К. Насильство у сім'ї - цивільно-правові аспекти. Організаційноправові засади запобігання домашньому насильству: реалії та перспективи: матеріали круглого столу, 31 травня 2019 р. за ред. О.П. Рябчинської. Запоріжжя: КПУ, 2019. $174 \mathrm{c}$.

4. Назимко E.С., Андріяшевська М.С. Міжнародний досвід та основні риси сучас- них зарубіжних кримінологічних практик запобігання вчиненню злочинів проти дітей. Вісник Асочіациї кримінального права України. 2018. № 2(11). C.155-167.

5. Зінсу O.I. Міжнародно-правові стандарти та зарубіжний досвід у сфері запобігання, протидії домашньому насильству. Нaуковий вісник Начіональної академї внутрішніх справ. 2021. №1 (118). C. 31-40. URL: https:// scientbul.naiau.kiev.ua/index.php/scientbul/article/view/1340/1340

6. Христова Г.О. Насильство в сім’ї та шляхи його попередження: законодавчий аспект. URL: http://www.khpg.org/ru/index. php?id $=12154408$

7. Міжнародний білль про права людини. Виклад фактів / Харківська правозахисна група. Харків: Фоліо, 2004. 62 с.

8. Декларація про права дитини від 20 листоп. 1959 р. Верховна Рада України. URL: http:// www.zakon2.rada.gov.ua/laws/ show/995 384.

9. Стромило А. П. Насильство над дітьми та його наслідки. Вісник Черкаського університету. Науковий журнал. 2010.№ 121. С. 140-143.

10. Конституція України : Закон України від 28.06.1996 р. № 254к/96-BP. URL: https://zakon.rada.gov.ua/laws/show/254k/96вр\#Text (дата звернення 05.10.2021).

11. Про охорону дитинства: Закон України від 26.04.2001 р. №2402-III. URL: $\underline{\text { https:// }}$ zakon.rada.gov.ua/laws/show/2402-14\#Text

12. UNICEF (2005). UN Human Rights Standards and Mechanisms to Combat Violence against Children: A Contribution to the UN Secretary-General's Study on Violence against Children. Florence, UNICEF Innocenti Research Centre.

13. UNICEF (2005). UN Human Rights Standards and Mechanisms to Combat Violence against Children: A Contribution to the UN Secretary-General's Study on Violence against Children. Florence, UNICEF Innocenti Research Centre.

14. Нєбитов А. А. Генеза міжнародноправових норм у сфері протидії сексуальній експлуатації. Право.иа. 2016. №2. С. 137-144.

15. Яхязаде Е. М. Насильство в сім’ї: міжнародний досвід та сучасні проблеми в Україні. Вісник Дніпропетровсъкого 


\section{АНОТАЦІЯ}

У науковій статті визначено, шо на съогодні насильство є однією з гострих сочіальних проблем як Украӥни, так і всъого світового свівтовариства. Иого жертвами водночас можуть ставати як жінки, так $і$ чоловіки, проте, за міжнародною статистикою, переважна частина насильницьких дій спрямовується саме на жінок та дітей. Визначено, що кожна дитина має право на фізичну та особисту недоторканість та захист від усіх форм насильства. Проаналізовано статистичні дані щодо проявів насильства щодо дітей в Україні та світі. Досліджено генезу міжнародно-правових документів, які покликані запобігти та протидіяти будь-яким проявам насильства щодо дітей. Визначено, що до міжнародноправових документів, покликаних регулювати ию сферу, $є$ Женевсъка декларація прав дитини, Декларачія прав дитини, Конвениія ООН про права дитини, Всесвітня деклараиія про забезпечення виживання, захисту $i$ розвитку дітей, Факультативний протокол до Конвениії ООН про права дитини, щодо торгівлі дітьми, дитячої проституий $i$ дитячой порнографбї, Протокол про попередження $i$ припинення торгівлі людьми, особливо жінками $і$ дітьми, $і$ покарання за нё̈, що доповнюе Конвениію Організачиї Об’єднаних Начій проти трансначіональної організованої злочинності, Конвениія МОП № 182 про заборону та негайні заходи щодо ліквідащй найгірших борм дитячої праці.

Крім изъого, у прочесі дослідження було проаналізовано національне законодавство, яке сбормувалось у результаті зобов'язань України на міжнародній арені. Розглянуто приниип забезпечення найкращих інтересів дитини у Декларацй прав дитини. Проаналізовано практику Европейсъкого суду з прав людини стосовно справ, пов'язаних з насильством щодо дітей. Сбормовано пропозицй для зменшення або й викорінення насильства, спрямованого на дітей. Впровадження вказаних позитивних заходів для попередження та ліквідаиї всіх форм насильства щодо дітей та ебективно реагувати на факти його вчинення, унеможливлюючи безкарність зловмисників.

Ключові слова: міжнародно-правові стандарти, насильство щуодо дітей, запобігання та протидія насильству, міжнародно-правові aкmu.

\section{SUMMARY}

In the scientific article it is determined that today violence is one of the acute social problems of both Ukraine and the whole world community. Its victims can be both women and men, but according to international statistics, the bulk of violence is directed at women and children. It is determined that every child has the right to physical and personal integrity and protection from all forms of violence. Statistics on manifestations of violence against children in Ukraine and the world are analyzed. The genesis of international legal documents designed to prevent and counteract any manifestations of violence against children has been studied. It is determined that one of the most important international legal instruments designed to regulate this area is the Geneva Declaration of the Rights of the Child, the Declaration of the Rights of the Child, the UN Convention on the Rights of the Child, the Universal Declaration on the Survival, Protection and Development of Children. on Trafficking in Children, Child Prostitution and Child Pornography, Protocol to Prevent, Suppress and Punish Trafficking in Persons, Especially Women and Children, supplementing the United Nations Convention against Transnational Organized Crime, ILO Convention No. 182 on the Prohibition and Immediate measures to eliminate the worst forms of child labor.

In addition, in the course of the research, the national legislation, which was formed as a result of Ukraine's obligations in the international arena, was analyzed. The principle of ensuring the best interests of the child in the Declaration of the Rights of the Child is considered. The case law of the European Court of Human Rights on cases of violence against children is analyzed. Proposals have been made to reduce or eradicate violence against children. Implement these positive measures to prevent and eliminate all forms of violence against children and respond effectively to the facts of its commission, preventing impunity for perpetrators.

Key words: international legal standards, violence against children, prevention and counteraction to violence, international legal acts.

університету імені Альфреда Нобеля. Серія : Юридичні науки. 2013. № 2.C. 120-125. URL: http://nbuv.gov.ua/UJRN/ vdujn_2013_2_23 